\title{
The Development of Institutional Models for Community Food Security in West Nusa Tenggara (Ntb) Province-Indonesia
}

\author{
Enirawan ${ }^{1}$, Setia Hadi $^{2}$, Bambang Juanda ${ }^{2}$, Ernan Rustiadi ${ }^{2}$ \\ ${ }^{1}$ Student of Post-graduate School with a Study Program of Regional and Rural Planning and Development \\ Science-Faculty of Economic and Management- Bogor Agriculture University -Indonesia) \\ ${ }^{2}$ Lecturers of Post-graduate School with a Study Program of Regional and Rural Planning and Development \\ Science-Faculty of Economic and Management-Bogor Agriculture University-Indonesia)
}

\begin{abstract}
NTB province is a food surplus area, but at the same time it belongs to an area that has a high risk of food shortage. Therefore, NTB should require a handling priority in this particular aspect. In the community, there are groups that can follow the market mechanism, but there are also groups with low incomes who need community institutions or mechanisms outside the market. This study aimed to develop models of community institutions to improve food security in NTB. The analytical methods used were Analysis of Food Security, Institutional Descriptive Analysis, Analysis of Transaction Cost (TC) and Path Analysis. The research result showed that the income and food stocks of families and patterns of community interactions in NTB through social transfers had increased the food security of individuals / families in NTB. Development models of community institutions to improve food security, among others, were diversification of family economic activities, encouragement of community participation both in formal and informal institutions, rural infrastructure development, Posyandu revitalization, Raskin arragements, and institutional integration, especially informal institutions in order to improve food security.
\end{abstract}

Keywords: community institution, food security, social transfer, transaction cost

\section{Introduction}

NTB province is a food surplus area as indicated by the value of the rice production surplus and the availability of food crops and foods of animal origin which is likely to increase. However, the existing data show that some areas in NTB are still included in 100 regencies in Indonesia being in danger of food shortage. In fact, approximately $70.83 \%$ of the total number of sub-districts in NTB are vulnerable to food shortage (FSVA, 2009 and Government of NTB, 2010).

The issue of food security in NTB province is mainly related to the sufficient food availability at the regional level, but in terms of the distribution and consumption at the community and individual / family levels, the province is facing potential problems. In the community, there are groups that can follow the market mechanism, but there are also groups with low incomes who need community institutions or mechanisms outside the market. Schotter (1981) defines an institution as the regulation of human behavior that is accepted by all members of the community and serves as an interaction pattern in a certain recurrent situation.

In the traditional arrangements, the people of NTB province initially had local institutions that managed food security in accordance with their need, e.g. village barns or scarcity barns, but unfortunately various local institutions and traditional knowledge systems relating to food security are gradually fading away (Karyadi LW, 2009). Then came policies and formal institutions that touched the lives and activities of community food security, but according to Arifin B (2005), the effectiveness of the various policies / institutional arrangements is still questionable.

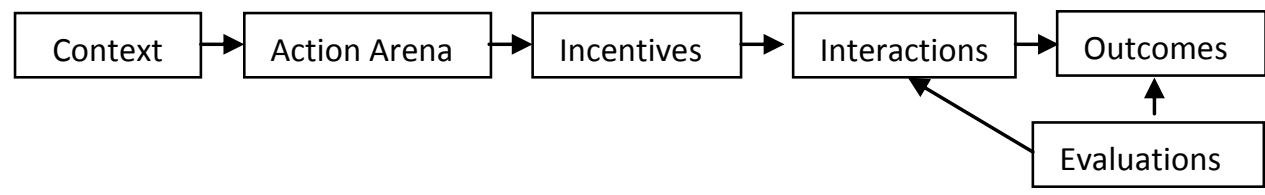

Figure 1. The Most General Elements of Institutional Analysis (Ostrom et al, 2002, ):

Related to the efforts to develop institutions, particularly the ones at community level, Ostrom et al. (2002) presents a framework or an analytical flowchart of institutional development efforts (Figure 1), that is, by identifying the actor situation (action arena) that has direct relevance to the problems studied, the context that shapes and influences the actor situation (including other relevant arenas) and behavioral interactions (Patterns of interaction) and the outcomes obtained. 
Karyadi LW (2009) has identified the forms, importance and dynamics of food security institutions at the community level in NTB, and finds that the presence of formal food system (as a form of system adaptation to technological development) culturally and institutionally has cornered the original food stock institutions.

Since the question raised in this research is concerning a proper institutional development model at the community level to improve food security in line with the regional characteristics and the community in NTB province, the aims of this research were: (1) to analyze Income and Food Stock (IFS) and their contributions to individual and family food security levels in NTB; (2) to analyze patterns of community interaction (social solidarity / social transfer) and their contribution to individual and family food security levels in NTB; and (3) to formulate a model of community institutional development to improve food security in NTB.

\section{Methods}

This research was conducted in the regencies of Dompu and Sumbawa (Sumbawa Island) and in the regencies of Central Lombok and West Lombok (Lombok Island), NTB province. The first objective was achieved using Analysis of Individual / Family Food Security and t-test. The second objective was reached using a descriptive analysis of Social Transfer (ST) and a desctiptive analysis of Transaction Cost (TC) in addition to the previous analysis. The third objective, which was a synthesis, was attained using a descriptive analysis of institutions in addition to the previous kinds of analyses, and all the models were tested with a path analysis.

\subsection{Analysis of Individual / Family Food Security}

Analysis of Family Food Security was carried out using cross-classification of two indicators of food security, namely food spending share and energy (kcal) consumption adequacy levels as shown in Table 1.

Table 1. Determining the Level of Individuals / Family Food Security

\begin{tabular}{|c|c|c|}
\hline \multirow{2}{*}{$\begin{array}{l}\text { Energy consumption per unit - equivalent } \\
\text { to aduts (Kcal) }\end{array}$} & \multicolumn{2}{|l|}{ Food spending share } \\
\hline & $\begin{array}{l}\text { Low } \quad(<60 \% \\
\text { spending })\end{array}$ & High $(>60 \%$ total spending) \\
\hline $\begin{array}{l}\text { Adequate }(>80 \% \text { energy adequacy } \\
\text { requirement })\end{array}$ & 4. Food secure & 3. Food vulnerable \\
\hline $\begin{array}{l}\text { Inadequate }(<80 \% \text { energy adequacy } \\
\text { requirement })\end{array}$ & $\begin{array}{l}\text { 2. Food questionable } \\
\text { (inadequate) }\end{array}$ & 1. Food Insecure \\
\hline
\end{tabular}

Source : Jonsson and Toole (1991) in Maxwell, D et al. (2000)

\subsection{Test of difference ( $t$ test)}

- To find out the differences in the average income and food stocks between regions / islands, $t$ test was done: two simple assuming unequal variances

- To find out the differences in the average energy consumption level and the spending on food before and after social transfer, $\mathrm{t}$ test was conducted: paired two simple for means

\subsection{Descriptive Analysis of Social Transfer (TS)}

Social Transfer $(\mathrm{TS})=$ Relatives Transfer + Zakat + Community Loan + Other Transfers (arisan, mbolo Weki, banjar, etc.)

\subsection{Descriptive Analysis of Transaction Cost (TC)}

Transaction Cost $(\mathrm{TC})=$ costs of search and information, meetings and decision-making process, monitoring, evaluation and enforcement of agreements (rules), and so on

\subsection{Descriptive Analysis of Institution}

Institutional analysis includes institutional identification and role analysis

\subsection{Path Analysis}

Path Analysis is an analysis that is used to explore the effects (whether direct or indirect) between variables. The path analysis in this study used LISREL 8.3 software, and the path analysis included such model diagram construction, preparation of model equations and model estimation. 


\section{Regional General Conditions}

NTB province has an area of $49,312.19 \mathrm{~km}^{2}$, consisting of two large islands, namely Lombok Island with an area of $4,738.80 \mathrm{~km}^{2}(23.51 \%)$ and Sumbawa Island with an area of $15,414.45 \mathrm{~km}^{2}(76.49 \%)$. Administratively, NTB province consists of eight regencies and two cities, namely West Lombok, Mataram City, North Lombok Regency, Central Lombok Regency and East Lombok Regency (located on Lombok Island) and West Sumbawa Regency, Sumbawa Regency, Dompu Regency, Bima City and Bima Regency (located on Sumbawa Island). NTB has a population of 4,587,562 in 2012. The percentage of population aged above 15 who worked in the available occupations in NTB in 2012 was $44.25 \%$ in the agricultural sector, $18.83 \%$ in the trade sector, $16.05 \%$ in the service sector and the rest in other sectors.

\section{Results And Discussion}

1.2. Income and Food Stock (IFS) and Their Contribution to Individual / Family Food Security Levels

To assure a reliable and sustainable level of individual / family food security, it is imperative to pay a special attention to two indicators of food security: the share of food expenditure and the level of energy consumption adequacy. Tables 2 and 3 explain that the average level of food security of individual / family respondents in NTB is still at the level of food vulnerable. This condition was actually the contribution of the average indicators of the food consumption share / capita of 0.95 and the food expenditure share of 0.71 . The data explained that in the short-term the average consumption of the community had fulfilled energy adequecy (> $80 \%$ energy adequacy requirement), but because the average total spending was low, the share of food expenditure was more dominant (> $60 \%$ of total family expenditure) which indicated that on the average the individuals / families were in a status of food vulnerable.

Table 2. Values of Income and Food Stock (IFS) Family Respondents in NTB

\begin{tabular}{|c|c|c|c|c|c|c|c|}
\hline No. & $\begin{array}{l}\text { Component } \\
\text { (Monthly per capita) }\end{array}$ & Unit & Dompu & Sumbawa & Loteng & Lobar & NTB \\
\hline 1 & $\begin{array}{l}\text { Average of Income and Food } \\
\text { Stock (IFS) }\end{array}$ & Rp.000 & 403.8 & 661.7 & 328.7 & 391.2 & 446.3 \\
\hline & IFS $\leq \mathrm{Rp} 250,000$ & $\%$ & - & 12.50 & 25.00 & 25.00 & 15.63 \\
\hline & $\begin{array}{l}\text { IFS }>250,000- \\
\leq R p 500,000\end{array}$ & $\%$ & 81.25 & 43.75 & 68.75 & 62.50 & 64.06 \\
\hline & $\begin{array}{l}\text { IFS }>500,000- \\
\leq \mathrm{Rp} 1,000,000\end{array}$ & $\%$ & 18.75 & 18.75 & 6.25 & 6.25 & 12.50 \\
\hline & IFS $>$ Rp $1,000,000$ & $\%$ & - & 25.00 & - & 6.25 & 7.81 \\
\hline 2 & Coefficient of IFS Variation & & 0.33 & 0.64 & 0.38 & 0.61 & 0.64 \\
\hline 3 & $\begin{array}{lrr}\text { Difference } \quad \text { Test } & \text { (t-test, } \\
\text { significant at } \alpha=5 \%) & \\
\end{array}$ & & The a & IFS Sur & land > Lol & $\mathrm{k}$ Island & \\
\hline
\end{tabular}

Source: Processed primary data

Based on t-test, the average income and food stocks of Sumbawa Island was higher than Lombok Island (significant at $\alpha=5 \%$ ). The next t-test showed that the average energy consumption of Sumbawa Island was higher than Island of Lombok, while the average share of food expenditure of Sumbawa Island was lower than Lombok Island (significant at $\alpha=5 \%$ ). This suggested that the level of food security in Sumbawa Island was relatively higher than in Lombok Island. The result of path analysis indicated that the increase in energy consumption adequacy and the decrease in the share of food expenditure were influenced by the increase in family expenditure (significant at $\alpha=5 \%$ ), while the increase in spending could be boosted through the increased incomes and food stocks (significant at $\alpha=5 \%$ ) and the decrease in transaction cost (significant at $\alpha=$ $10 \%$ ).

Table 3. Levels of Energy Consumption, Food Sepending, and Food Security Levels of Individual / Family Respondents in NTB Province

\begin{tabular}{llllllll}
\hline No. & $\begin{array}{l}\text { Component } \\
\text { (Monthly per capita) }\end{array}$ & Unit & Dompu & Sumbawa & Loteng & Lobar & NTB \\
\hline 1 & Consumption Energy Level (CEL) & Index & 1.00 & 0.96 & 0.92 & 0.91 \\
\hline 2 & $\begin{array}{l}\text { Spending Share } \\
\text { (SSF) Family }\end{array}$ & Food & Index & 0.72 & 0.55 & 0.81 & 0.76 \\
\hline 3 & $\begin{array}{l}\text { Food Security Level } \\
\text { Individual/Family }\end{array}$ & (FSL) & & & & & \\
\hline $3 \mathrm{a}$ & Food Insecure & $\%$ & - & 12.50 & 12.50 & 12.50 \\
\hline $3 \mathrm{~b}$ & Food Inadequate & $\%$ & - & - & - & - \\
\hline $3 \mathrm{c}$ & Food Vulnerable & $\%$ & 5.00 & 25.00 & 62.50 & 62.50 \\
\hline $3 \mathrm{~d}$ & Food Secure & $\%$ & 25.00 & 62.50 & 25.00 & 25.00 \\
\hline 4 & $\begin{array}{l}\text { Difference Test (t-test, significant } \\
\text { at } \alpha=5 \% \text { ) }\end{array}$ & $-\begin{array}{l}\text { The average CEL of Sumbawa Island }>\text { Lombok Island } \\
\text { The average SSF of Sumbawa Island < Lombok Island }\end{array}$ \\
\hline
\end{tabular}


Source: Processed primary data

\subsection{Community Interaction Patterns (Social Solidarity / Social Transfer) and Their Contribution to Individual / Family Food Security Levels}

Food security is a collective problem; therefore, it is necessary for a community in a social arrangement to organize collective actions to solve the problem, for instance, through social solidarity in the form of social transfers to individuals / families in need. Social solidarity / social transfer can increase income and food stock and family spending.

Table 4. Community Interaction Patterns (Social Transfer and Transaction Cost) and Its Contribution to Individual / Family Food Security Level

\begin{tabular}{|c|c|c|c|c|c|c|c|}
\hline No. & $\begin{array}{l}\text { Component } \\
\text { (Monthly per capita) }\end{array}$ & Unit & Dompu & Sumbawa & Loteng & Lobar & NTB \\
\hline 1 & Social Transfer (TS) from Community & $\mathrm{Rp}(000)$ & 41.32 & 11.25 & 33.47 & 7.24 & 23.58 \\
\hline 2 & $\begin{array}{lllll}\text { Transaction } & \text { Cost } & \text { (TC) in } & \text { Community } \\
\text { Institution }\end{array}$ & $\operatorname{Rp}(000)$ & 7.72 & 1.77 & 1.91 & 1.42 & 3.23 \\
\hline 3 & $\begin{array}{l}\text { Consumption Energy Level (CEL)-after social } \\
\text { transfer }\end{array}$ & Index & 1.00 & 0.97 & 1.00 & 0.95 & 0.98 \\
\hline 4 & $\begin{array}{l}\text { Spending Share Family Food (SSF)- after } \\
\text { social transfer }\end{array}$ & Index & 0.67 & 0.53 & 0.66 & 0.74 & 0.65 \\
\hline 5 & $\begin{array}{l}\text { Food Security Level (FSL) Individual/Family - } \\
\text { after social transfer }\end{array}$ & & & & & & \\
\hline $5 a$ & Food Insecure & $\%$ & - & 6.25 & - & 6.25 & - \\
\hline $5 b$ & Food Inadequate & $\%$ & - & - & - & - & - \\
\hline $5 c$ & Food Vulnerable & $\%$ & 62.50 & 25.00 & 62.50 & 62.50 & 62.50 \\
\hline $5 \mathrm{~d}$ & Food Secure & $\%$ & 37.50 & 68.75 & 37.50 & 31.25 & 37.50 \\
\hline 6 & Difference Test (t-test, significant on $\alpha=5 \%$ ) & & \multicolumn{5}{|c|}{$\begin{array}{l}\text { The average of CEL before social transfer < } \\
\text { after social transfer } \\
\text { The average of SSF before social transfer > } \\
\text { after social transfer }\end{array}$} \\
\hline
\end{tabular}

Source: Processed primary data

Table 4 illustrates that after social transfers the average level of the food security of individual / family respondents increased as evident from the t-test result showing that the average level of energy consumption in NTB province before social transfers was lower than that after social transfers, while the average share of food expenditure in NTB province before social transfers was higher than that after social transfers (significant at $\alpha=$ $5 \%)$. The result of path analysis indicated that the increase in food security was due to the increase in family expenditure. The increase in family expenditure was determined by the initial value of expenditure, driven through the increased social transfers to the community (significant at $\alpha=5 \%$ ).

The value of social transfers received by the family respondent per capita per month in NTB were on the average of $\mathrm{Rp} 23,580$, especially from relatives and zakat. The highest average of social transfer was in Dompu at Rp 41,320 per capita per month and Central Lombok Rp 33,470. Social transfers from zakat come from the residents who pay zakat through zakat officers/ mosque officers to be submitted to families who are entitled to receive. The kinship institutions in Dompu and Sumbawa are in form of neighbor relationship or familial relationship. Neighbor relationship is coordinated by the head of RT / RW and Village Head. Meanwhile, kinship in the regencies of Central Lombok and West Lombok is in the form of Gubug, namely the community relationship in a neighborhood unit which generally has family ties. Gubug is coordinated by Gubug senior which is more informal (custom function).

Raskin (low-priced rice to be sold to the poor), loans from the community and other kinds of "help" (in the form of arisan or banjar). The loans from the community for needy families are on the basis of trust, generally without margins, so as to be economically beneficial for the families. Another social transfer is in the form of arisan or banjar which is a form of institutional mechanism of sharing and mutual help and or the sharing of asset in form of cash and certain items. Social transfers in such institution as arisan or banjar are generally accepted at the community level, not specifically for poor families.

Social transfers done in NTB community have several motives. The most dominant motif was a habit / custom (76.56 \% of the respondents). Another motive was for the purpose of worship value (57.81\%), and in terms of worship motive $87.50 \%$ of respondents were from Central Lombok and West Lombok, while $56.25 \%$ respondents were from Sumbawa. The motive for property adequacy was $4.69 \%$, giving out of shame $4.69 \%$ and social sanctions of $3.13 \%$. These data suggest that social transfers have been institutionalized and sustained 
because of the awareness of applying custom or spiritual value in addition to the structure of incentives and disincentives (sanctions).

\subsection{Community Institutional Development Model to Improve Food Security}

The preparation of an institutional community development model was carried out by considering the relations among outcome component, family spending, spending on food, level of energy consumption (food) and level of food security, which are determined by the patterns of interaction (social solidarity / social transfers) and the action arena (income and food stocks ) and context (biophysical environment, community attributes, and the role of institutions in the food security and livelihoods and the role of citizens in the institutions). The test results of PATH conformity criteria showed an institutional development model of food security at the community level in NTB province (Figure 2) meet the criteria of goodness of fit (with indicators, among others, P-value $=0.05489>0.05$ and the value of RMSEA-Root Mean Square Error of Approximation $=$ $0.064 \leq 0.08)$.

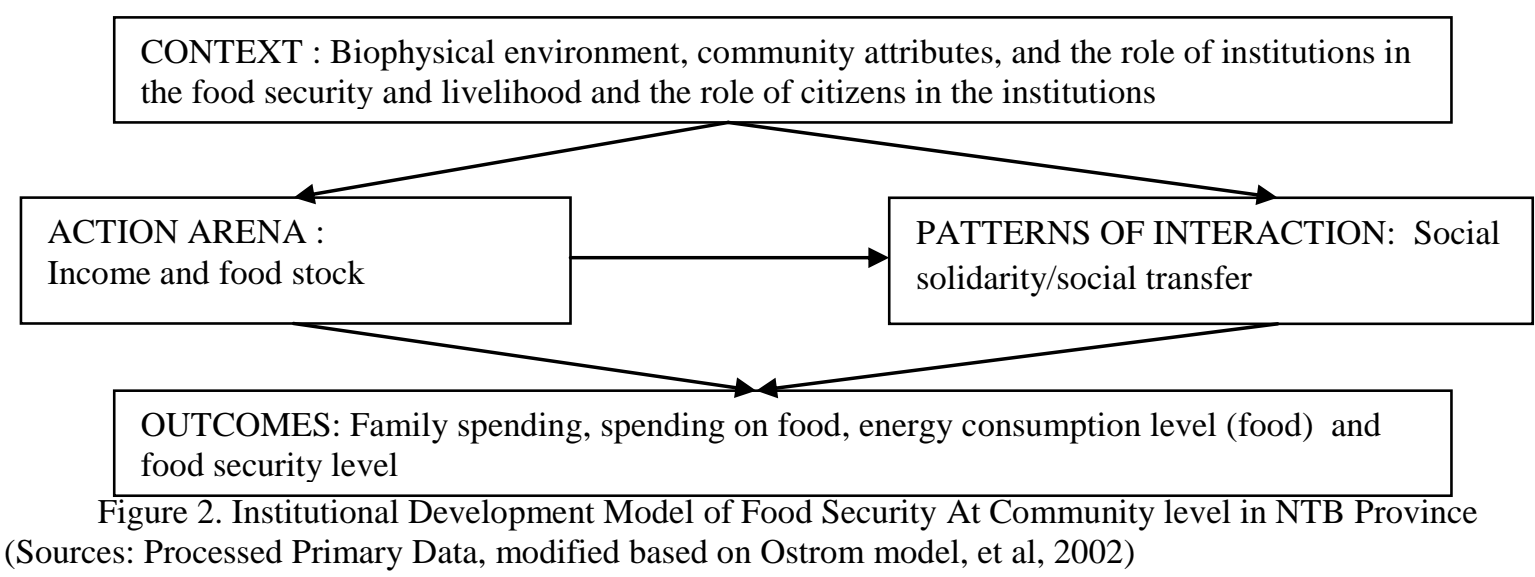

The analysis result with a path model described that to achieve the desired outcomes, namely the increase in spending potential and individual / family food security level, it is necessary to increase family income and food supply, decrease transaction costs and increase social transfers from community and community through a model of institutional development described below.

The first objective was to increase income and food stocks (IFS). As for other (potential) problems, among others, the average IFS were approaching the poverty line, the low presence of economic and financial institutions, particularly in villages (its existence only contributed to $20.31 \%$ of respondents) and the low participation of citizens in institutions ( $70.79 \%$ were not active in the institutional community). To achieve the objective, the strategy was by increasing IFS (among others, through family economic diversification), citizens participation in institutions, and institutiona roles related to economic activities / family food security.

Sumbawa Island has such potentials as agricultural land, plantations and farms (owned by individual, family or community), creating opportunities for families to do economic diversification in agriculture, plantations and farms. Business mechanism is coordinated through agricultural land-based groups and shared grazing landbased livestock (Institutional Lar), which is supported by the agencies of Agriculture, Plantation and Animal Husbandry.

On the island of Lombok, the farmland is on the decrease, whereas the activities of tourism, trade and services have greatly increased, opening opportunities for families to do economic diversification in the form of home industry and services. These businesses are conducted through community economic groups, among others, supported by the agencies of Industry and Trade, Cooperatives and SMEs, and Tourism.

To support family economic diversification, it is necessary to have economic institutional facilities and community-based financial institutions that are supported by the the agencies of Industry and Trade, Cooperatives and SMEs, and Banking Institutions / Non-banking Financial Institutions

The second objective was to lower transaction cost (TC). The potential / problem was the lack of accessibility, so the strategy used was to increase the accessibility of transport, information and communication, especially in rural areas. To execute the strategy, there should be efforts to encourage the mechanisms of community meeting, mutual help, sharing and cooperation, including rural infrastructure development (transport, information and communication) through planning and budgeting at regional level (APBD/APBN).

The third objective was to increase social transfers (ST). To help poor families, the goverment has provided a special program called Raskin although the allocation is still low (15 kg / family), not to mention in its 
implementation in the field where a family can only get 5-6 kg. Therefore, Raskin program cannot be expected to raise the nutritional status and food security of poor families. On the other hand, the utilization of the institutional community in food security early warning system is still low. For that purpose, the strategy required is to arrange Raskin and the institutional community.

At the stage of data collection and Raskin distribution, control mechanism is needed using such mechanisms as bottom-up (from residents) and top-down (from the government). This way it is expected that the distribution of Raskin will reach the target. However, to assure that the rice food will reach the right individual, Raskin should be allocated on the basis of normative food need for individuals and the number of family members.

In addition to structuring Raskin policy, the local capacity should also be increased to ensure food security through the development of community-level barns and area supported by community resources (family barn, communal barns, banjar, arisan, etc.) which are supported by village government, traditional institutions, Agency for Rural Development, Food Security Agency, Food Security Agencyl and other parties.

In institutional development, it is necessary to note on the institutional characteristics of each region. The institutional characteristics that contribute to food security and the lives of residents on the island of Sumbawa which is dominantly characterized by formal institutions such as farmer group institutions and government institutions. The community on the island of Lombok has the potential of informal institutions that contribute to the livehood of the residents and food security such as institutional Gubug (institutional unit of residential area / kinship), banjar institutions (mutual help and asset sharing in the form of money or goods), and religious institution / teacher institution (playing a role in the transfer of knowledge and religious teachings, and having an influence in decision making at community level). Informal institutions according to North (1990) are the institutions in the community (usually unwritten), customs, traditions, taboos, conventions and other types with a variety of other names and titles.

In the implementation of the mechanisms / institutions above, in the event of a dispute or conflict in resource management or in transaction activities and social interactions at community level, there is an institutional arbitration, where the Village Head / Village Government is supported by the rules in the form of Village Regulations (Perdes) while in the community on the island of Lombok there is a traditional institution called Gubug senior, supported by rules in the form of Awik - Awik (customary laws).

In various areas in NTB, Posyandu institutions are easily found. Historically, these institutions have a relatively well-established arrangement in the New Order era. However, in the following era, relatively less attention has been given by the government so that the role of Posyandu in food security was relatively low $(3.13 \%)$. Therefore, it is necessary to revitalize Posyandu, which could be integrated with educational and women institutions. The existence of Posyandu is expected to play a role in implementing early warning systems and additional intake of nutrition, providing information and basic care of children, mothers and the elderly.

To enhance the institutional role in improving food security, it is necessary to increase citizen participation in formal and informal institutions as well as institutional integration, particularly informal institutions in an effort to improve food security.

\section{Conclusion And Recommendation}

\subsection{Conclusion}

1) Income value and Family food stock (IFS) in NTB which were relatively low contributed significantly to individual / family food security level, namely with a status of food vulnerable.

2) Social interaction, among others, in the form of social solidarity / social transfer (ST) could significantly increase individual / family food security level in NTB.

3) Community institutional development model in improving food security in NTB, among others, through family economic diversification, increased citizen participation in community institutions, rural infrastructure development, Posyandu revitalization, Raskin arrangement as well as institutional integration, especially informal institutions in an effort to improve food security.

\subsection{Recommendation}

1) To increase the value of family income and food stock (IFS) in NTB through business diversification should pay attention to the socio-economic characteristics of the region. In so doing, it is expected that in Sumbawa Island there shoul be a synergy between government working units and other related parties to develop the agricultural sector, plantations and farms, while in Lombok Island it is conducted through home industry activity and service sector at the community level.

2) To encourage social transfer (ST) mechanisms at the community level which are initially more oriented to cultural activities / traditional ceremonies to be adopted with the aim of enhencing food security.

3) Community institutional development model should consider institutional characteristics. Sumbawa Island is dominantly characterized by formal institution, so that various mechanisms of improving food security can be 
strengthened, among others, through village regulations (Perdes) and the improvement of Village Government capacity, while in Lombok Island Community informal (traditional) institutions should be strengthened through the utilization and preservation of Awik - Awik (customary rules) as well as the capacity improvement of the role of adatl institutions, teacher institution and other institutions

4) Further research is required to study community institutional development model more deeply with a narrower area scope (eg regency), and to learn about linkages at every institutional level (center-regioncommunity).

\section{References}

[1] Arifin B., Ekonomi Kelembagaan Pangan. LP3ES. Jakarta, 2005

[2] BPS NTB, Provinsi NTB dalam Angka tahun 2012. BPS NTB. Mataram, 2013

[3] FSVA, Peta Ketahanan dan Kerentanan Pangan Indonesia. Dewan Ketahanan Pangan Departement Pertanian. World Food Programe (WFP). Jakarta, 2009.

[4] Jonsson, U., and D. Toole. Household food security and nutrition: A conceptual analysis. New York: United Nations Children's Fund. Dalam Maxwell, D and T.R. Frankenberger. 1992. Urban livelihoods and food and nutrition security in Greater Accra, Ghana. IFRI in Collaborative with Noguchi Memorial for Medical Research and World Health Organization. Research Report No. 112. Washington, D.C, 1991.

[5] Karyadi LW. Strategi dan pengembangan masyarakat lokal menghadapai perubahan lingkungan akibat aktivitas pertambangan di daerah lingkar tambang PT. Newmont Nusa Tenggara. Universitas Mataram. Mataram, 2005.

[6] Karyadi. LW. Perubahan sosial diperdesaan Nusa Tenggara Barat. Rekonstruksi kelembagaan sosial asli untuk penanganan dan pencegahan rawan pangan. Universitas Mataram. Mataram, 2009.

[7] North DC. Institutions, institutional change and economics performance. Cambridge University Press, 1990.

[8] Ostrom E. Governing of the common.The evolution of institutions for collective action.Cambridge University Press, 1990.

[9] Ostrom E, Gibson C, Shivakumar S, Andersson K, Aid, Incentives, and Sustainability an Institutional Analysis of Development Cooperation. Workshop in Political Theory and Policy Analysis, Indiana University, 2002.

[10] Pemerintah Provinsi NTB. Rencana aksi daerah pangan dan gizi. Pemerintah Provinsi NTB. Mataram . 2010

[11] Schotter A. The economic theory of social institutions. Cambridge, Cambridge University Press. 1981. 